NBER WORKING PAPER SERIES

\title{
ESCAPING FROM A LIQUIDITY TRAP AND DEFLATION: THE FOOLPROOF WAY AND OTHERS
}

\author{
Lars E.O. Svensson \\ Working Paper 10195 \\ http://www.nber.org/papers/w10195
NATIONAL BUREAU OF ECONOMIC RESEARCH
1050 Massachusetts Avenue
Cambridge, MA 02138 \\ December 2003
}

Lars E.O. Svensson is Professor of Economics at Princeton University, Princeton, New Jersey. He is also Research Fellow, Centre for Economic Policy Research, London, United Kingdom and Research Associate, National Bureau of Economic Research, Cambridge, Massachusetts. His homepage is www.princeton.edu/ svensson. The views expressed herein are those of the authors and not necessarily those of the National Bureau of Economic Research.

(C)2003 by Lars E.O. Svensson. All rights reserved. Short sections of text, not to exceed two paragraphs, may be quoted without explicit permission provided that full credit, including (C) notice, is given to the source. 
Escaping from a Liquidity Trap and Deflation: The Foolproof Way and Others

Lars E.O. Svensson

NBER Working Paper No. 10195

December 2003

JEL No. E52, F31, F33, F41

\title{
$\underline{\text { ABSTRACT }}$
}

Existing proposals to escape from a liquidity trap and deflation, including my "Foolproof Way," are discussed in the light of the optimal way to escape. The optimal way involves three elements: (1) an explicit central-bank commitment to a higher future price level; (2) a concrete action that demonstrates the central bank's commitment, induces expectations of a higher future price level and jump-starts the economy; and (3) an exit strategy that specifies when and how to get back to normal. A currency depreciation is a direct consequence of expectations of a higher future price level and hence an excellent indicator of those expectations. Furthermore, an intentional currency depreciation and a crawling peg, as in the Foolproof Way, can implement the optimal way and, in particular, induce the desired expectations of a higher future price level. I conclude that the Foolproof Way is likely to work well for Japan, which is in a liquidity trap now, as well as for the euro area and the United States, in case either would fall into a liquidity trap in the future.

\author{
Lars E.O. Svensson \\ Department of Economics \\ Fisher Hall \\ Princeton University \\ Princeton, NJ 08544-1021 \\ and NBER \\ svensson@princeton.edu
}




\section{Introduction}

In the last decade or two, central banks all over the world have been quite successful in achieving low and stable inflation. Average annual inflation in the industrialized countries has fallen to a level below 2 percent. Average inflation has not been so low since the 1950s, as shown in Table 1 . In emerging countries, inflation is now the lowest since the 1960s (International Monetary Fund (2003b)).

Table 1. Average annual inflation in industrial countries (consumer price index, percent)

$\begin{array}{cc}1950-59 & 2.8 \\ 1960-69 & 3.2 \\ 1970-79 & 8.2 \\ 1980-89 & 5.6 \\ 1990-99 & 2.7 \\ 2000-03 & 1.8\end{array}$

(Source: International Monetary Fund (2003b).)

These gains against inflation are good news. They have brought substantial benefits in terms of reduced distortions, less uncertainty, and improved resource allocation. But they also raise new risks. Unanticipated negative shocks to demand or supply can always cause recessions and lower inflation - and, starting from a low inflation level, even deflation. In such a situation, the appropriate response by central banks is to lower interest rates and this way stimulate the economy out of recession and too low inflation. But with low inflation or even deflation, a negative interest rate may be required to provide sufficient stimulus to the economy, whereas nominal interest rates cannot fall below zero. The economy might then become caught in a liquidity trap and a prolonged recession and deflation.

This paper begins with a discussion of the causes and consequences of a liquidity trap and deflation, with some emphasis to Japan's experience since the 1990s. It then discusses policy options for preventing a liquidity trap and deflation from occurring and for escaping from a liquidity trap and deflation if they have already occurred. Whereas policy for avoiding a liquidity trap and deflation is less controversial, there is a fair amount of controversy about the range of policies to escape from a liquidity trap and deflation, including my own proposal, the "Foolproof Way" (Svensson (2001, 2002)).

\section{Causes and Consequences of a Liquidity Trap and Deflation}

How can a liquidity trap and deflation arise, and why are they a problem? An increasing number of central banks aim both to stabilize inflation around a low level and to keep output close to its potential level. But monetary policy operates under considerable and unavoidable uncertainty about the state of the economy and the size and lag of the economy's response to monetary-policy actions. Unanticipated shocks to demand and supply are unavoidable. Because of the lags in the effect of monetary-policy actions, good central banks are forward-looking, use available 
information about the economy and anticipated shocks to construct forecasts of inflation and output, and respond to these forecasts as best as they can. A substantial realized or anticipated negative shock to aggregate demand, because of, for instance, the bursting of an asset-price bubble, a correction of overoptimistic growth and productivity expectations, increased doubts about future pensions and benefits due to demographic developments and/or reckless fiscal policy, increased uncertainty for geopolitical or other reasons, will lower both actual inflation and output as well as forecasts of future inflation and output. If initial inflation is low, this may be all that is needed for not only a temporary recession but a temporary deflation.

When central-bank forecasts indicate recession and too low inflation or even deflation, the appropriate response is to lower the central bank's "instrument rate," the short(-maturity) nominal interest rate it uses to implement monetary policy - the federal funds rate in the United States. A lower short nominal interest rate, combined with sluggish private-sector inflation expectations, will lowers the short real interest rate - the nominal rate less expected inflation. Expectations of lower future short real rates then lower longer(-maturity) real rates, the rates that matter for consumption and investment decisions and thereby aggregate demand. The lower real rates, with some lag, stimulate aggregate demand and output and bring the economy out of recession. Increased aggregate demand and increased inflation expectations then increase actual inflation, also with some lag. On occasion, a competent or lucky central bank may even be able to preempt the recession and too low inflation more or less completely. Such successful preemption is a central banker's dream.

If the nominal interest rate is initially low, which it is when inflation and expected future inflation are low, the central bank does not have much room to lower the interest rate further. But with deflation and expectations of deflation, even a nominal interest rate of zero percent can result in a substantially positive real interest rate that is higher than the level required to stimulate the economy out of recession and deflation. Nominal interest rates cannot fall below zero, since potential lenders would then hold cash rather than lend at negative interest rates. This is the socalled "zero lower bound for interest rates."

In particular, conventional monetary policy seems unable to provide sufficient stimulus to the economy and address recession and deflation once the zero lower bound for interest rates has been reached. The problem is that the economy is then satiated with liquidity and the private sector is effectively indifferent between holding zero-interest-rate Treasury bills and money. In this situation, standard open-market operations by the central bank to expand the monetary base by buying Treasury bills lead the private sector to hold fewer Treasury bills and more money - but this has no effect on prices and quantities in the economy. When this "liquidity trap" occurs, expanding liquidity (the monetary base) beyond the satiation point has no effect. If a combination of a liquidity trap and deflation causes the real interest rate to remain too high, the economy may sink further into a prolonged recession and deflation. ${ }^{1}$

Prolonged deflation can have severe negative consequences. The real value of nominal debt rises, which may cause bankruptcies for indebted firms and households and a fall in asset prices. Commercial banks' balance sheets deteriorate when collateral loses value and loans turn bad, and financial instability may threaten. Unemployment may rise, and if nominal wages are rigid

\footnotetext{
${ }^{1}$ Keynes used the term "liquidity trap," but there is considerable uncertainty about what he meant (Sumner (2002)).
} 
downwards, deflation means that real wages do not fall but increase, further increasing unemployment. All this may contribute to a further fall in aggregate demand, a further increase in deflation, a further increase in the real interest rate, and bring prices and the economy down in a deflationary spiral. Therefore, a liquidity trap with the associated risk of a prolonged recession or even a deflationary spiral is a central banker's nightmare.

Japan's recent experience provides a stark warning of the dangers of a liquidity trap and deflation. Japan has already lost a decade to economic stagnation and deflation. Without effective policy measures, it may very well lose another decade. Whatever the reasons for Japan's initial recession and stagnation, most observers of Japan's experience have concluded that the reason for the prolonged stagnation and deflation is due to policy mistakes and an inability to take decisive and coordinated action to resolve Japan's problems. The policy measures that have been tried have not succeeded in ending stagnation and deflation. Expansive fiscal policy, with a big fiscal deficit, has not ended stagnation but has lead to huge national debt, close to 150 percent of GDP at the end of 2001 and still increasing (International Monetary Fund (2002)). With regard to monetary policy, Bank of Japan lowered the interest rate to zero and kept it there from February 1999 to August 2000, and again from March 2001 until now. From March 2001, after long indecisiveness, it also attempted a so-called "quantitative easing," a substantial expansion of the monetary base. During two years up to the spring of 2003, the monetary base was increased by about 50 percent (Bank of Japan (2003)). But these steps were not sufficient to induce a recovery. As the Japanese economy faces expectations of further deflation, the real interest rate remains positive and too high. But, as will be discussed and as many frustrated observers have repeated, there are more effective policy measures for ending recession and deflation that the Japanese authorities have declined to apply.

Deflation in Japan measured with the GDP deflator began in 1995. Since 1999 the GDP deflator has been falling at a rate of between 1 and 2 percent per year. Deflation in the consumer price index began in 1999, and since then the consumer price index has been falling at a rate slightly less than 1 percent per year (International Monetary Fund (2003a)). Thus, deflation in Japan is still relatively modest and has not started to increase dramatically. This indicates that the problem is not a dramatic deflation in itself but the recession, the zero lower bound and the liquidity trap preventing monetary policy to provide sufficient stimulus to the economy.

Japan does not only have a macroeconomic problem of recession and deflation; it also has many structural and microeconomic problems, especially in the financial sector (for instance, Kashyup (2002)). Ending recession and deflation is not a substitute for solving those structural problems and undertaking structural reforms. But it can be easier to solve those problems and undertake the necessary reforms in a growing economy with positive inflation. So far, the Japanese authorities have demonstrated the same inability to handle the structural problems as the macroeconomic ones.

During the Great Depression, deflation in the United states during the three years from 1930-1932 was more dramatic, about 10 percent per year. During the same time, industrial production fell by 50 percent and GDP by almost 30 percent. There is broad agreement that monetary factors and mistakes by the Federal Reserve played a crucial role both in the onset and prolongation of the Great Depression (Meltzer (2003) and International Monetary Fund (2003a)). 
In the United States today, low inflation and a sluggish recovery from recession in 2002 and 2003 has also led commentators and policymakers to worry about the risk that new unfavorable shocks could topple the United States into a liquidity trap and even deflationary spiral (for example, Ahearne et al. (2002); Bernanke (2002)). In the euro area, low inflation and recession in Germany has led some commentators and policymakers to be concerned about the risk of Germany experiencing deflation (for example, The Economist (2002b); Issing (2002)). In May 2003, the International Monetary Fund issued a report from a special task force on deflation in the world (International Monetary Fund (2003a)) and a certain media frenzy was notable.

\section{Escaping from a Liquidity Trap and Deflation}

Many researchers and policymakers have recently discussed the consequences of the zero bound, a liquidity trap and deflation, how to avoid becoming trapped, and how to escape if trapped, often with specific references to Japan. ${ }^{2}$ There seems to be considerable agreement on how to avoid the zero bound and a liquidity trap and minimize the risk that it happens. Many papers recommend an explicit positive symmetric inflation target (say 2 percent per year), to give a sufficient margin to deflation. Many central banks already conduct forward-looking inflation targeting, trying to take preemptive actions if inflation forecasts are too low or too high relative to the inflation target. Another possibility is to set a target path for the price level in the future, perhaps rising at 2 percent per year, although no central bank currently implements explicit price-level targeting as distinct from price-level targeting (more on this below). Svensson (1999a) has suggested that prudent central banks should prepare in advance a set of emergency measures, to be used at preannounced indications of an imminent liquidity trap. Some of these emergency measures will be further discussed below.

Less agreement exists on how to escape from a liquidity trap and deflation, if the economy has already fallen into a liquidity trap and the real interest rate is too high for appropriate stimulus of the economy. This section will discuss a variety of practical proposals for such escape. These proposals include: announcing a positive inflation target; announcing a price-level target path; expanding the monetary base via open-market operations in Treasury bills and more unorthodox assets; reducing long interest rates via a ceiling on long interest rates or via a commitment to keep the instrument rate equal to zero for a substantial time in the future; depreciating the currency by foreign-exchange interventions; introducing a time-varying exchange-rate target; introducing a tax on money; introducing more expansionary fiscal policy; affecting intertemporal substitution of consumption and investment by time-variable tax rates; and, finally, a policy of combining a pricelevel target path, a currency depreciation and a crawling peg, and an exit strategy that makes up my Foolproof Way to escape from a liquidity trap.

\section{The Optimal Way to Escape from a Liquidity Trap}

Given that the central bank cannot reduce the nominal interest rate below zero, what is the best way to escape from the recession and deflation? The real interest rate is the difference between the nominal interest rate and expected inflation. Thus, even if the nominal interest rate is constant at

\footnotetext{
${ }^{2}$ Some useful references are available in two recent conference volumes, Fuhrer and Sniderman (2002) and Bank of Japan (2001). Clouse et al. (2003) contains a detailed discussion of monetary policy options with a zero interest rate.
} 
zero, the central bank can affect the real interest rate, if it can affect private-sector inflation expectations. If the central bank could manipulate private-sector beliefs, it would make the private sector believe in future inflation, the real interest would fall, and the economy would soon emerge from recession and deflation.

The problem is that private-sector beliefs are not easy to affect. A few decades back, when inflation was high, central banks would often promise low future inflation, but the private sector often paid little attention. Often, high inflation continued to rule. Similarly, if a central bank in a liquidity trap promises high inflation in the future, the private sector may doubt either the ability or the will of the central bank to achieve that future inflation. The central bank may be tempted to cheat, that is, to promise high future inflation to get out of the liquidity trap, but once out renege on the promise and keep inflation low. Indeed, the situation can be described as one of multiple equilibria. If the private sector is pessimistic and expects deflation, the real interest rate will remain high and the recession and deflation will be longer. If the private sector is optimistic and expects deflation to be replaced by inflation, the real interest rate will be lower and the recession and deflation will be shorter.

Let us consider the best possible rational-expectations equilibrium in this situation, that is, when the private sector believes in the central bank's promise and the central bank lives up to its promise. Suppose that the central bank prefers to keep inflation close to a given small but positive explicit or implicit inflation target and output close to potential output. In the recession and deflation, output is below potential and inflation is below target. Sometime in the future, the liquidity trap will end, inflation will return close to target, and output will return close to potential. For the bank, it would be better to overshoot the inflation target intentionally in the future, since this would correspond to higher inflation expectations and a lower real interest rate and help the economy out of the current liquidity trap. The loss of higher-than-target future inflation would be compensated by higher output and less deflation in the current liquidity trap.

Thus, the best possible rational-expectations equilibrium is one where the central bank intentionally conducts more expansionary policy and causes a higher inflation in the future so as to shorten the current recession and deflation. This policy also implies keeping the nominal interest rate at zero for some period even after the recession and deflation is over. Rational private-sector expectations of this policy will then lower the real interest rate in the liquidity trap. The basic insight into the nature of this optimal policy is due to Krugman (1998). The precise derivation of the optimal policy in some specific circumstances is presented in Jung, Teranishi and Watanabe (2001) and Eggertsson and Woodford (2003).

As Krugman has emphasized, the problem is that this optimal policy may not be credible. Once the recession and deflation is over, the central bank may renege on its promise of a future expansion and instead keep inflation low and close to its target rate. Indeed, if the private sector's preferences agree with the bank's, the private sector would also prefer that, once the recession and deflation is over, inflation is held close to its low target rate. But if this outcome is anticipated, private-sector inflation expectations will remain low and the recession and deflation will be longer. The central bank would need to commit itself to the future monetary expansion, and also communicate this commitment to the private sector. But with the normal instrument, the instrument rate, already constant at zero, it is difficult to demonstrate any commitment. Thus, it is natural to discuss 
proposals for ending deflation according to the nature of the commitment to future monetary expansion they involve, and how such commitment can be demonstrated in the current period and be effective in inducing private-sector expectations of a higher future inflation.

\section{Announcing a Positive Inflation Target or a Price-Level Target Path}

Several authors have proposed the announcement of a sufficiently positive inflation target as a commitment to a higher future inflation rate (for instance, Bernanke (2000); Krugman (1998); Posen (1998)). In line with the optimal policy of a future overshooting of the normal inflation target, this target should be higher than normal for a few years. Krugman (1998) has stated that the central bank should "credibly promise to be irresponsible," by which he means setting an inflation target higher than might otherwise be desirable. For Japan, Krugman (1998) has suggested a relatively high 4 percent inflation target for 15 years. Posen (1998) has suggested a more modest initial inflation target of 3 percent, to be reduced to 2 percent after a few years.

However, the mere announcement of an inflation target and a future monetary expansion need not be credible with the private sector and therefore need not affect inflation expectations, in the absence of any commitment mechanism or any action supporting the announcement. Thus, this method is therefore more likely to work if it includes published inflation forecasts, transparent inflation reports, public hearings, and other elements increasing the commitment to the inflation target. Even so, the private sector may expect a higher than normal inflation target to be adjusted downward once the liquidity trap is over. In particular, for a central bank like the Bank of Japan or the Federal Reserve, that have for many years publicly resisted announcing an inflation target, the announcement of any inflation target may be interpreted as an unconvincing "gallows speech," to be disregarded when the liquidity trap is over.

Another possibility is to announce an upward-sloping target path for the price level, perhaps rising at 1-2 percent per year, as suggested for Japan in Svensson (2001) and more recently by Bernanke (2003). The practical difference between these two approaches is that if inflation falls short of the inflation target in one year, the inflation target for the next year does not change. However, with a price level target, lower inflation in one year must be counterbalanced by a higher rate of inflation in future years to return to the desired price level path. In the context of escaping from a liquidity trap, a price-level target offers an advantage above an inflation target, since long-term inflation expectations matter more than short term. Long real interest rates are long nominal rates less longterm inflation expectations. If a central bank with an inflation target is expected to undershoot its inflation target for a couple of years and then return to it (which a central bank in a liquidity trap might be expected to do), then long-term average inflation is lower, since the bank does not compensate in the future for past misses. However, if a central bank with a price-level target is expected to undershoot its target for a couple of years and later return to it, long-term inflation expectations are unaffected by the initial misses. Furthermore, if deflation occurs and the price level falls further below the target, inflation and inflation expectations will rise to get back to target. Thus, further deflation automatically lowers the real interest rate even if the nominal rate is constant (at zero, for instance).

A price-level target path could even start above the current price level with a "price gap" to undo. As emphasized by Bernanke (2000, 2003), several years of zero or negative deflation may have 
resulted in a price level below previous expectations that has increased the real value of debt and deteriorated balance sheets for banks and firms. For Japan, this price gap may be 10-15 percent or more.

Thus, a price-level target, if credible, has an advantage in corresponding to more desirable longterm inflation expectations as well as the undoing of a price gap. Indeed, Eggertsson and Woodford (2003) show that the optimal rational-expectations equilibrium for escaping from the liquidity trap is best expressed as a price-level target path rather than an inflation target that disregards past misses. Indeed, they argue that, from a credibility point of view, it is better to follow a price-level target before a liquidity trap occurs than to announce it once the liquidity trap occurs. This is a general argument in favor of price-level targeting rather than inflation targeting. No central bank currently implements explicit price-level targeting, although Sweden did so during part of the 1930s (Berg and Jonung (1999)). ${ }^{3}$

Announcing an inflation target or a price-level target will lower the real interest rate and be expansionary only to the extent that the targets are credible with the private sector. Since the standard policy tool of a lower short interest rate is neutralized by the zero bound, it is natural to look for other instruments of monetary policy that can potentially demonstrate the central bank's commitment.

\section{Expanding the Monetary Base}

Although the zero lower bound prevents lowering the nominal interest rate below zero, the central bank can still expand the monetary base (Benhabib, Schmitt-Grohé and Uribe (2002); Bernanke (2000); Clouse et al. (2003); Meltzer (2001); Orphanides and Wieland (2000)). However, the precise mechanism through which an expanded monetary base will alter expectations is not altogether clear.

For example, Meltzer (2001) suggests that an expanded monetary base will affect a number of other asset prices and interest rates in an expansionary direction, even if short nominal interest rates are zero, especially depreciating the domestic currency. But, in a liquidity trap, Treasury bills and money are approximately perfect substitutes, and open-market operations increasing private holdings of money and reducing private holdings of Treasury bills would have little or no effects on other asset prices and interest rates.

Therefore, an expansion of the monetary base would increase inflation expectations and reduce the real interest rate only if it is seen as a permanent expansion. Indeed, Krugman (1998) expressed the desirable future monetary expansion in terms of an increased future money supply. In principle, the central bank could expand the monetary base without limit, by continually buying domestic and foreign government debt, and if these are exhausted, other domestic and foreign assets. Such a

\footnotetext{
${ }^{3}$ Aside from the liquidity-trap aspects, it is an open question whether, away from the zero bound, inflation targeting or price-level targeting is the preferred policy. Conventional wisdom has been that price-level targeting would imply more short-term inflation variability and/or output-gap variability. This conventional wisdom has recently been challenged by Svensson (1999b), Vestin (2003), Batini and Yates (2003) and Cecchetti and Kim (2003), where it is shown that different forms of price-level targeting or a combination of inflation and price-level targeting may very well reduce short-term inflation and/or output-gap variability, in addition to reducing long-term price-level uncertainty.
} 
dramatic policy would eventually affect private-sector expectations and have a dramatic effect on the domestic price level and the exchange rate and certainly put an end to deflation.

The problem is, again, why an expansion of the monetary base today should be viewed as a commitment to increased money supply in the future. While the liquidity trap lasts and the interest rate is zero, the demand for monetary base is perfectly elastic and excess liquidity is easily absorbed by the private sector. However, once the liquidity trap is over and the nominal interest rate is positive, demand for money will shrink drastically, in most cases requiring a drastic reduction of the monetary base. It is difficult to assess how much the monetary base would have to be expanded before inflation expectations and inflation take off. Beyond some unknown threshold, deflation may be quickly replaced by hyperinflation. As noted above, the Bank of Japan has expanded the monetary base by about 50 percent in the two years prior to the summer of 2003; given this step, it will definitely have to contract the monetary base once the liquidity trap is over. Thus, a commitment not to reduce the monetary base at all in the future is not credible, but a commitment to reduce it by less than otherwise is a more complex matter. ${ }^{4}$ The private sector may anticipate that the central bank will immediately back off any expansion of the monetary base if it fears igniting inflation, which in turn could make the initial commitment to monetary-base expansion not credible, implying that initial monetary base expansion has little or no effect; as has indeed been the case for the substantial increase of the monetary base in Japan.

\section{Reducing Long Interest Rates}

Even if short nominal interest rates are zero in a liquidity trap, long nominal interest rates need not be. As already noted, it is longer real interest rates, rather than short real rates, that affect consumption and investment decisions. Thus, a reduction of long nominal interest rates could, everything else equal, reduce long real rates and hence be expansionary and contribute to an escape from the liquidity trap. Several researchers and policymakers have therefore suggested openmarket operations in long bonds as a way of reducing long interest rates (for instance, Clouse et al. (2003); Lebow (1993); Meltzer (2001)).

It is difficult to determine how large an open-market operation would be needed to reduce the long interest rate, because of difficulties in estimating the determinants of the term premium of interest rates (that is, the difference between long and short interest rates and its dependence on the degree of substitutability between short and long bonds). However, Bernanke (2002) has proposed an elegant operational solution to this problem. The central bank simply announces a low (possibly zero) interest-rate ceiling for government bonds up to a particular maturity, and makes a commitment to buy an unlimited volume of those bonds (that is, potentially the whole outstanding volume) at that interest rate. This commitment by the central bank is readily verifiable - since everyone can verify that the central bank actually buys at the announced interest rates - and achieves the desired impact on the long interest rate, without a need to specify the precise magnitude of the open-market operation required. The central bank may have to buy the whole outstanding issue of the long bond, though.

\footnotetext{
${ }^{4}$ This circumstance creates some difficulties for the proposal of Auerbach and Obstfeld (2003) that the central bank just needs to make a permanent expansion of the monetary base.
} 
Another way to reduce long bond rates, proposed by Orphanides and Wieland (2000), relies on the expectations hypothesis that long bond rates are related to expectations of future short nominal rates. They suggest a commitment by the central bank to maintain the short nominal interest rate at zero for a substantial time in the future, even if the economy recovers. This proposal is in line with the optimal way to escape from a liquidity trap that was described above, which involves a zero interest rate also after the economy has recovered. But as discussed earlier, it is not clear that this commitment can be made credible.

Even if the central bank may be able to reduce long bond rates, this may not provide sufficient stimulus to the economy. That is, without the creation of long-term inflation expectations, the resulting long real interest rate may still be too high.

\section{A Tax on Money}

Goodfriend (2002) and Buiter and Panigirtzoglou (1999) have proposed an unorthodox way of eliminating the zero bound on nominal interest rates by introducing a tax on money. Such a tax would allow negative nominal interest rates in equilibrium, and allow the central bank to achieve the desired stimulating negative interest rate.

It is technically feasible to introduce a tax on commercial-bank reserves in the central bank and on electronic money, such as consumer cash cards. However, introducing a tax on currency requires technological innovations like electronic chips in the notes or a lottery that determines what numbered notes in a series become worthless in each period. It could also imply the inconvenience of notes circulating with the same denomination but trading at different discounts. One might also anticipate some public resentment against a system that would makes some of the money in people's pockets conspicuously worthless.

\section{Fiscal Policy}

Fiscal policy is an obvious policy alternative in a liquidity trap, when traditional monetary policy is ineffectual. However, the effectiveness of this policy depends to a considerable extent on the reactions of the private sector.

For example, if the initial level of government debt is high and a higher debt is deemed unsustainable, a policy of higher government debt may cause the private sector to anticipate tax increases or government benefit reductions in the near future. A resulting increase in private-sector saving will then reduce any impact of the expansionary fiscal policy.

Depending on the degree of independence of the central bank, the private sector might also anticipate that increased budget deficits will be financed by the central bank, which would presumably lead to inflation expectations. However, in Japan, expansionary fiscal policy over a number of years has led to a dramatic increase in the government debt, without stimulating the economy out if its recession and liquidity trap. For Japan, a further bond-financed fiscal expansion may be neither effective nor accepted by lenders without substantial interest-rate increases, which would defeat the stimulus. A money-financed fiscal expansion - that is, a budget deficit financed by the printing press, or more precisely, by the central bank buying the government bonds issued to 
finance the deficit - may still be expansionary, since a money-financed fiscal expansion need not necessarily be followed by eventual tax increases or expenditure cuts. Bernanke (2003) proposes that a price-level target for Japan is combined with a money-financed fiscal expansion. But, again, the expansion of the money supply need even in this case not be permanent and credible, since in the future concern about too high inflation may induce the central bank to reduce the money supply and increase the outstanding government debt.

Fiscal policy can also be used in another way in a liquidity trap, namely to lower the real interest rate net of taxes and subsidies (Saxonhouse (1999); Feldstein (2002)). A temporary reduction in the value-added tax combined with a temporary investment tax credit will reduce the after-tax real interest rate. By combining these policies with a temporary surcharge on the income and corporate tax, these tax changes can be fully financed and need not affect the budget deficit. One potential problem with such temporary tax changes is that they need not be credible. That is, the private sector may believe that the government will not reverse the tax cut as soon in the future as promised, taking into the account that the government may be tempted to prolong any stimulating effect by postponing the reversal. But an anticipated more permanent tax reduction will have less effect on the after-tax real interest rate. From this point of view, a temporary tax reduction that is less than fully financed may be more credible.

\section{Currency Depreciation}

Even if the nominal interest rate is zero, a depreciation of the currency provides a powerful way to stimulate the economy out of the liquidity trap (for instance, Bernanke (2000); McCallum (2000); Meltzer (2001); Orphanides and Wieland (2000)). A currency depreciation will stimulate an economy directly by giving a boost to export and import-competing sectors. More importantly, as noted in Svensson (2001), a currency depreciation and a peg of the currency rate at a depreciated rate serves as a conspicuous commitment to a higher price level in the future, in line with the optimal way to escape from a liquidity trap discussed above. An exchange-rate peg can induce private-sector expectations of a higher future price level and create the desirable long-term inflation expectations that are a crucial element of the optimal way to escape from the liquidity trap.

In order to understand how manipulation of the exchange rate can affect expectations of the future price level, it is useful to first review the exchange-rate consequences of the optimal policy to escape from a liquidity trap outlined above. That policy involves a commitment to a higher future price level and consequently current expectations of a higher future price level. A higher future price level would imply a correspondingly higher future exchange rate (when the exchange rate is measured as units of domestic currency per unit foreign currency, so a rise in the exchange rate is a depreciation, a fall in the value, of the domestic currency). ${ }^{5}$ Thus, current expectations of a higher future price level imply current expectations of a higher future exchange rate. But those expectations of a higher future exchange rate would imply a higher current exchange rate, a current depreciation of the currency. The reason is that, at a zero domestic interest rate, the exchange rate must be expected to fall (that is, the domestic currency must be expected to appreciate) over time approximately at the rate of the foreign interest rate. Only then is the expected nominal rate of

\footnotetext{
${ }^{5}$ Recall that the economy will be out of the liquidity trap in the future and back to normal. Then the relative price between domestic and foreign goods is back to its normal, long-run equilibrium level. For a given such relative price and a given foreign price level, the exchange rate is proportional to the domestic price level.
} 
return measured in domestic currency on an investment in foreign currency equal to the zero nominal rate of return on an investment in domestic currency; this equality is an approximate equilibrium condition in the international currency market. That is, the current exchange rate must approximately equal the expected future exchange rate plus the accumulated foreign interest (the product of the foreign interest rate times the time distance between now and the future). But then, at unchanged domestic and foreign interest rates, the current exchange rate will move approximately one to one with the expected future exchange rate. If the expected future exchange rate is higher, so is the current exchange rate. Indeed, the whole expected exchange-rate path shifts up with the expected future exchange rate. Thus, we have clarified that the optimal policy to escape from a liquidity trap, which involves expectations of a higher future price level, would result in an approximately equal current depreciation of the currency.

This has the important consequence that the current exchange rate immediately reveals whether any policy to escape from a liquidity trap has succeeded in creating expectations of a substantial increase in the future price level. If it has, this appears as a substantial current depreciation of the currency. Consequently, if the currency does not depreciate substantially, the policy has failed. Regarding Japan, from 1999 to the summer of 2003, the yen has fluctuated in the interval 105-130 yen per dollar with an average of about 117. In the year prior to the summer of 2003, the average rate has been about 120 . Hence, there has not been any substantial depreciation. Consequently, any policy in Japan, including the quantitative easing with the 50 percent expansion of the monetary base in the two years to the summer 2003, has apparently not succeeded in any substantial increase in the expected future price level.

However, the desired initial depreciation of the currency can be achieved directly by the central bank. Indeed, the central bank can directly achieve the desired optimal exchange-rate path associated with the optimal policy to escape from the liquidity trap. The initial depreciation of the currency will then induce private-sector expectations of a future depreciation and, importantly, of a higher future price level, the crucial element in escaping from a liquidity trap. Thus, by a current depreciation of the currency, the central bank can induce private-sector expectations of a higher future price level and in this way make its commitment credible.

For simplicity, the discussion here is in terms of a central bank that controls both monetary policy and exchange-rate policy. In many countries, including the United States and Japan, the responsibility for exchange-rate policy rests with the department of the treasury or the ministry of finance rather than the central bank. This situation is problematic, a potential source of conflict and unclear responsibilities, and even a potential threat to central-bank independence, since monetary and exchange-rate policy are, under free international capital mobility, not independent but just two sides of the same coin. Because of such institutional imperfections, exchange-rate policy as discussed here must in many countries actually be done in cooperation between the central bank and the department of the treasury/ministry of finance.

Let us take the argument step by step. First, how can the central bank achieve the desired initial depreciation of the currency and implement the desired exchange-rate path? It can do this by announcing a crawling peg: a new high initial exchange rate and the gradual fall over time of the exchange rate at a fixed rate approximately equal to the average foreign interest rate. In particular, the central bank should announce that it will buy and sell unlimited amounts of foreign exchange at 
the announce exchange rate. If this crawling peg would fail, the domestic currency would appreciate back to the vicinity of the exchange rate before the announcement, making the currency a good investment. Thus, initially, before the peg's credibility has been established, there will be excess demand for the currency. This demand is easily fulfilled, however, since the central bank can print unlimited amounts of its currency and trade it for foreign exchange. ${ }^{6}$

Remember, it may be difficult and even impossible to defend the peg of a currency under pressure for depreciation, because the central bank must sell off its foreign exchange reserves to support the currency and those reserves eventually run out. In contrast, it is easy to defend a peg of a currency under pressure for appreciation, because this defense calls for the bank to issue more domestic currency and hold greater foreign-exchange reserves, which it can without limit. Thus, the peg can be defended and the peg's credibility will soon be established.

Second, why would the peg induce expectations of a higher future price level? Once the peg is credible, since the expected exchange-rate path has shifted up by the initial depreciation, the private sector must believe that the future exchange rate will be higher. But then internal consistency requires that the private sector must also expect a higher future price level (since they have no reason to believe that the future relative price between domestic and foreign goods will move in any particular direction). Thus, the initial depreciation, the credible peg and internal consistency forces the private sector to expect a higher future price level.

Thus, the initial depreciation and the crawling peg gives the central bank a concrete action by which it can demonstrate its commitment and induce the desired private-sector expectations. Depending on how quickly the peg becomes credible, the central bank may have to buy more or less foreign exchange, thus adding to its foreign exchange reserves. Interestingly, the existence of these reserves gives the central bank an internal balance-sheet incentive to maintain the peg, since abandoning the peg and allowing the currency to depreciate back to its initial level would result in a capital loss for the central bank. Thus, the central bank is actually putting its money where its mouth is, thereby reinforcing the commitment.

The argument can be further illustrated in figure 1. The horizontal axis shows time; the current period is denoted by 0 and the future is denoted by $T$. The vertical axis displays (the logarithm of) the price level and the exchange rate. Initially, the current price level is $p_{0}$ and deflation and the liquidity trap would gradually bring the price level down to the level $p_{T}$ in the future, corresponding to the downward-sloping line $p_{0} p_{T}$. Initially, the current exchange rate is $s_{0}$, and it is expected to fall at the rate of the foreign interest rate to $s_{T}$ in the future, corresponding to the downward-sloping solid line $s_{0} s_{T}$. The lines $p_{0} p_{T}$ and $s_{0} s_{T}$ need not be parallel, since the rate of deflation need not equal the foreign interest rate.

\footnotetext{
${ }^{6}$ Furthermore, no currency trader can trade at a different exchange rate than that announced by the central bank: Suppose that some trader offers to buy and sell the domestic currency at an exchange rate that is intermediate between the previous exchange rate and the central bank's new higher rate. Then other traders can make a profit by buying the domestic currency cheaply from the central bank and selling it more expensively to this trader, instantaneously making a profit, whereas the trader is making a loss. The trader would soon be out of a job.
} 
Figure 1. The price level and the exchange rate

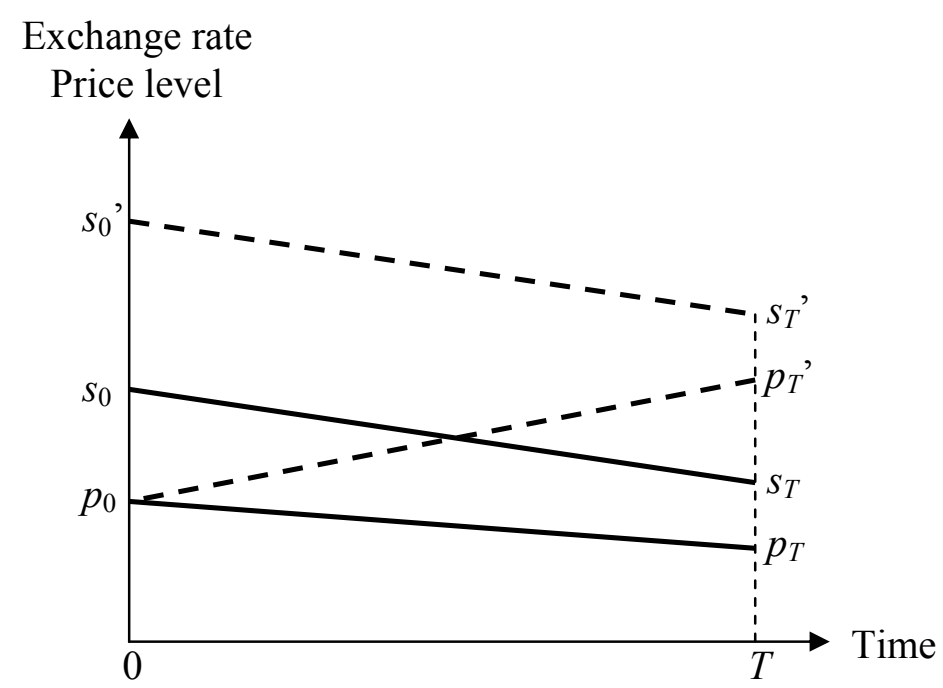

Suppose that the optimal way to escape from a liquidity trap involves the higher future price level $p_{T}$, higher than the future price level $p_{T}$, and a price-level path corresponding to the upwardsloping dashed line $p_{0} p_{T}$ '. The problem for the central bank is to make this higher future price level be credible, that is, expected by the private sector in the current period, so the private-sector's inflation expectations are sufficiently high, corresponding to the positive slope of the line $p_{0} p_{T}$ ' rather than the negative slope of the line $p_{0} p_{T}$. The exchange-rate path consistent with the optimal way to escape from the liquidity trap is $s_{0}$ ' $s_{T}$, , a parallel shift up of $s_{0} s_{T}$ by the same magnitude that the higher future price level $p_{T}$ ' exceeds $p_{T}$.

By raising the initial exchange rate from $s_{0}$ to $s_{0}$ ' and defending and establishing credibility for a crawling peg along $s_{0}$ ' $s_{T}$ ', the central bank induces expectations of the future exchange rate equal to $s_{T}$ ' and of the future price level equal to $p_{T}$ '. Once the crawling peg is credible, the private sector cannot expect a lower exchange rate (stronger currency) in the future than $s_{T}$, , since that would require a negative domestic interest rate. Any deterioration of the credibility of the peg would immediately show up in appreciation pressure on the currency, that is, a pressure downwards on the exchange rate and increased demand for domestic currency. But the central bank can immediately counter this by issuing more currency and buying more foreign exchange, thus restoring the credibility of the peg.

Suppose that the central bank would announce not a crawling but a constant peg at the level $s_{0}$ '. This would correspond to a horizontal line at the level $s_{0}$ ' in figure 1 . Once the central bank had established credibility for that constant peg, the private sector would expect the future exchange rate to equal $s_{0}$ '. This would imply expectations of a higher price level than the optimal $p_{T}$, higher than $p_{T}$ ' by the same magnitude as $s_{0}$ ' exceeds $s_{T}{ }^{\prime}$. Thus, this would correspond to a higher-thanoptimal future price level. Furthermore, the constant peg would not be consistent with a zero domestic interest rate; instead the domestic interest rate would have to be raised to equal the foreign interest rate (in order to fulfill the equilibrium condition of approximate equality of the expected 
rate of return on investments in domestic and foreign currency mentioned above). But, the higher expected future price level and thereby higher expected inflation compensates for the higher interest rate, so the real interest rate would still equal the optimal one. The central bank could avoid the too high future price level by announcing a constant peg at a lower exchange rate than $s_{0}$, but then the inflation expectations would be lower, and with the domestic interest rate still equal to the foreign one, the domestic real interest rate would be higher than optimal one, making the current recession deeper. Thus, the crawling peg with an appreciating exchange rate and a zero domestic interest rate provides the best tradeoff between current output and the future price level.

Several papers have suggested that the central bank depreciate the currency by general foreignexchange intervention; that is, by buying foreign-currency assets (foreign Treasury bills) and selling (paying with) domestic currency. This process increases the supply of assets denominated in domestic currency and reduces the supply of assets denominated in foreign currency. If domestic- and foreign-currency-denominated assets are imperfect substitutes, this process induces a depreciation of the domestic currency. The effect of relative asset supplies on the exchange rate is called the "portfolio-balance effect" in the literature. However, most empirical estimates of the size of any portfolio-balance effect have been quite small, and the practical importance of portfoliobalance effects is a matter of controversy (Sarno and Taylor (2001)). Consequently, it is difficult to predict how effective foreign-exchange interventions would be and what magnitude of intervention would be needed. Fortunately, the above implementation of the crawling peg as a commitment to buy and sell unlimited amounts of foreign exchange at the announced exchange rate does not rely on the existence of any portfolio-balance effects.

McCallum (2000, 2002, 2003) has proposed a moving exchange-rate target rather than an exchange-rate peg as a way to escape from a liquidity trap. The moving exchange-rate target would be a function of current inflation and the output gap, such that inflation below the inflation target or a negative output gap would result in a currency depreciation. McCallum has shown in simulations with an open-economy model that this moving exchange-rate target, if it is credible and understood by the private sector, can stimulate the economy out of a liquidity trap and deflation. This proposal implies a more indirect and more complex commitment to a higher future price level, although it could perhaps be combined with a price-level target path and an exit strategy when the price-level target path has been reached. ${ }^{7}$

A currency depreciation has proven to be an effective tool for fighting deflation in the past. As Bernanke (2002) notes: "A striking example from U.S. history is Franklin Roosevelt's 40 percent devaluation of the dollar against gold in 1933-34, enforced by a program of gold purchases and domestic money creation. The devaluation and the rapid increase in money supply it permitted ended the U.S. deflation remarkably quickly. Indeed, consumer price inflation in the United States, year on year, went from -10.3 percent in 1932 to -5.1 percent in 1933 to 3.4 percent in 1934."

\footnotetext{
${ }^{7}$ For Japan, McKinnon, for instance in McKinnon (1999), has proposed a bilateral agreement between the United States and Japan to permanently fix the exchange-rate between the dollar and the yen at approximately the current level. Although this step would end the liquidity trap, it would not be a commitment to a significantly higher price level than currently exists in Japan and would not provide any stimulus to the Japanese economy. Furthermore, a permanently fixed exchange rate between the yen and the dollar is unlikely to be sustainable, and above all, it is likely to be a very suboptimal monetary-policy arrangement for two economies as large and as different as the United States and Japan.
} 


\section{The Foolproof Way}

The previous discussion of the optimal policy and the practical proposals indicate three elements of a successful escape from a liquidity trap: 1) a commitment by the central bank to a higher future price level, preferably in the form of a price-level target, including any price-gap that the central bank prefers to undo; 2) a concrete action by the central bank that demonstrates its commitment to the higher future price level, induces corresponding private-sector expectations and reduces the real interest rate; and 3) an exit strategy that specifies when and how to get back to normal (and what that "normal" is). My proposal, the Foolproof Way to escape from a liquidity trap, attempts to combine these three elements (Svensson (2001)). Although this proposal was originally directed toward Japan, it applies to any open economy, that has fallen into a liquidity trap, and, should it be necessary in the future, would work well for both the United States and the euro area.

The Foolproof Way consequently consists of announcing and implementing three measures: 1) an upward-sloping price-level target path, starting above the current price level by a price gap to undo; 2) a depreciation and a crawling peg of the currency; and 3) an exit strategy in the form of the abandonment of the peg in favor of inflation or price-level targeting when the price-level target path has been reached.

As discussed in the previous subsection, a currency depreciation and a crawling peg is unique in providing the central bank with a concrete action that demonstrates the central bank's commitment to a higher future price level, establishes credibility for the peg, induces private-sector expectations of a higher future price level, and stimulates the economy by reducing the real interest rate. As argued, via a depreciation and a crawling peg with a rate of appreciation approximately equal to the average foreign interest rate, the central bank can actually implement approximately the optimal way to escape from a liquidity trap and strike the optimal balance between current stimulus of the economy and the future price level. ${ }^{8}$ Furthermore, as discussed, the exchange rate is unique in providing a relatively direct measure of the private-sector expectations of the future price level.

Once the Foolproof Way is implemented, the currency depreciation and the lower real interest rate will increase aggregate demand, jump-start the economy, and increase output towards potential. The depreciation, the closing of the output gap and the increased inflation expectations will increase the domestic price level (the GDP deflator). Finally, the consumer price index, as distinct from the GDP deflator, will increase not only from the increased GDP deflator but also from increased costs of imported final goods because of the currency depreciation. ${ }^{9}$ The domestic price

\footnotetext{
${ }^{8}$ The original version of the Foolproof Way in Svensson (2001) suggested a rate of crawl equal to the difference between the domestic inflation target and the average foreign inflation (in practice, an approximately constant peg) rather than the optimal negative rate of crawl equal to the average foreign interest rate. The original version would then have a positive domestic interest rate during the crawling peg (approximately equal to the foreign intereset rate) rather than a zero interest rate, which as discussed in the previous subsection results in a future price level or a real interest rate somewhat higher than the optimal one.

${ }^{9}$ Some media commentators like The Economist (2002a) and Financial Times (2002), as well as a number of newsletters from various investment banks, seem to assume for Japan that the only effects of a depreciation of the yen are a rise in the Japanese consumer price index due to increased import prices and a stimulation of exports. They have consequently concluded that the effect of an exchange-rate depreciation is modest. However, the effects of a depreciation and a peg of the yen go more deeply and increase inflation expectations and reduce the long real interest rate, as noted above.
} 
level will approach the price-level target path from below. When the price-level target has been reached, according to the exit strategy, the exchange-rate peg is abandoned, and the economy can get back to normal with the central bank adopting some form of inflation or price-level targeting.

\section{Conclusion}

The proposals to escape from a liquidity trap and deflation discussed in this paper provide a number of alternatives that can be used. Several of these proposals could be used simultaneously, in the hope that something works. The Bank of Japan has not followed any of these recommendations, except expanding the monetary base. That the Bank of Japan has not undertaken more genuinely expansionary policy, especially to take the initiative to cooperate with the Ministry of Finance to depreciate the currency, has led to widespread frustration among commentators. As expressed by Svensson (2001) (written before the futile quantitative easing): "The gist of the Bank of Japan's argument [against more expansionary policy] ... seems to be that, since one cannot be absolutely sure that any given policy action or change in the monetary policy regime will succeed in getting the economy out of the liquidity trap, it is safer not to try."

A recent paper by Coenen and Wieland (2003) presents a very interesting comparison of three methods for Japan to escape from deflation and the liquidity trap. The paper compares the Orphanides and Wieland's (2000) proposal to expand the monetary base, McCallum's moving exchange-rate target, and my Foolproof Way in an estimated and calibrated three-region model of Japan, the United States and the euro area. All three methods work in lifting Japan from recession and deflation, with small negative consequences for inflation and unemployment in the other two regions. However, this model assumes that all three methods are equally and fully credible, which is not necessarily the case, as discussed in some detail above. ${ }^{10}$

If either of the United States or the euro area would fall into a liquidity trap in the future, would the Foolproof Way work for them, too? Everything else equal, the more open an economy, the more sensitive it should be to a depreciation of the currency. Of these three economies, Japan is the least open economy, measured as the share of trade in GDP. Its export and import were, respectively, about 11 and 10 percent of GDP in 2001. For the euro area, these shares were about 20 and 19 percent; for the United States they were about 10 and 14 percent (European Central Bank (2003)). Thus, the United States and the euro area should be at least as sensitive to exchange-rate movements as Japan.

The simple version of the Foolproof Way discussed above takes the rest of the world as given. For instance, it is assumed that interest rates and inflation in the rest of the world is approximately unaffected. If the country that follows the Foolproof Way is too large relative to the rest of the world, this may not be the case. Of the three regions, Japan has the smallest GDP, a share of about 12 percent of world GDP at market exchange rates in 2002 (about 7 percent at purchasing-poweradjusted GDP; International Monetary Fund (2003b)). The shares of the euro area and the United States are about 21 and 33 percent, respectively (16 and 21 percent, respectively, at purchasing-

\footnotetext{
${ }^{10}$ Furthermore, for the proposal to expand the monetary base, a huge expansion of the monetary base is required, after which it falls back to approximately its initial level. The expansion of the logarithm of the monetary base is about 500 percent, corresponding to almost 15000 percent in the level of the monetary base. This raises some doubts about the practicality of expanding the monetary base as way to escape from a liquidity trap.
} 
power-adjusted GDP). Thus, the United States, the largest economy in the world, produces no more than a third of the world's GDP (and only about a fifth if we use purchasing-power-adjusted GDP). If the United States were to follow the Foolproof Way, interest rates and inflation in the rest of the world would not be unaffected, but they may not move that much either; if the euro area were to follow the Foolproof Way, they would clearly move less. The optimal way to escape from a liquidity trap for the euro area or the United States would involve expectations of a higher future price level which would be induced by the three elements of the Foolproof Way in the same way as they would for Japan. I conclude that the Foolproof Way is likely to be an effective way to escape from a liquidity trap and deflation for both the euro area and the United States.

There are two final issues to address about currency depreciation as a way to escape from a liquidity trap, like the Foolproof Way. First, a policy that calls for a depreciation relative to the rest of the world can work for Japan, or the United States, or the euro area, but if all three regions were simultaneously to fall into a liquidity trap, these regions could not all simultaneously depreciate against each other. However, if only one of them is in a liquidity trap, as is currently the case for Japan, it can apply the Foolproof Way and escape the liquidity trap. Having escaped, it then leaves any other region free to apply the Foolproof Way in the future, should that region be so unfortunate as to fall into a liquidity trap.

The second issue is whether escaping a liquidity trap via a currency depreciation has negative consequences for the trading partners of the country. When a country attempts to stimulate its economy by depreciating its currency, this is often called a "competitive devaluation" or a "beggarthy-neighbor policy," invoking associations of negative consequences for trading partners. For instance, Fischer (2001) suggests that a yen depreciation could not be pushed too far because of beggar-thy-neighbor concerns.

However, we have already seen that the optimal way to escape from a liquidity trap, which involves expectations of a higher future price level, would directly lead to a corresponding depreciation of the currency. Indeed, absence of a currency depreciation indicates a failure to induce such expectations. The Foolproof Way is just a method to implement approximately the optimal way to escape from the liquidity trap through the back door, by starting with a currency depreciation. Indeed, any expansionary monetary policy that succeeds in increasing expectations of the future price level and lowering the real interest rate will imply a currency depreciation. Thus, opposing a currency depreciation is an argument against any expansionary monetary policy - which seems nonsensical.

Because of the short-run stickiness of the domestic price level, a currency depreciation implies a temporary real currency depreciation, that is, an increase in the price of foreign goods relative to domestically produced goods and services. This is a terms-of-trade improvement for the trading partners and in itself beneficial to them. But one concern is that this will increase the domestic trade balance, the net export from the country and hence decrease the net export to the country from the trading partners. But the effect on the trade balance involves both a substitution and an income effect, of opposite signs. The substitution effect due to the change in relative prices from a depreciation favors domestic exporters and import competitors and increases the trade surplus (or reduces the trade deficit). But the income effect due to increased output, consumption and investment in the domestic economy implies increased import of raw materials, intermediate inputs 
and final goods and reduces the trade surplus (or increases the trade deficit). The net effect on the trade balance may therefore be quite small, as indicated by simulations in Coenen and Wieland (2003) and McCallum (2003). Thus, a currency depreciation will involve some sectoral shifts, but it need not involve any beggar-thy-neighbor policy. For Japan, with an economy operating far below potential GDP, the income effect on the trade balance, which is favorable to the trading partners, could actually be quite large.

Furthermore, and importantly, to the extent that the Foolproof Way has any contractionary effects and reduces output and inflation in the rest of the world, the rest of the world can respond with lower interest rates and monetary expansion. In this way, a desirable world-wide monetary expansion is implicitly coordinated by countries pursuing domestic monetary objectives, as is discussed recently by Obstfeld and Rogoff (2002), Corsetti and Pesenti (2003), and Benigno and Benigno (2002). ${ }^{11}$

Generally, it would seem that it would be in the interest of the world as a whole to end the decadelong stagnation and recession in Japan, the world's second largest economy. Concern about relatively minor effects of a currency depreciation would seem to be relatively irrelevant to this overall world interest. It seems obvious that the East-Asian region, the United States, and the world as a whole would all benefit in the medium and long term from a Japanese recovery and a strong Japanese economy.

- The author has benefited from discussions with Bennett McCallum and Volker Wieland. He thanks Kathleen DeGennaro and Kathleen Hurley for editorial and secretarial assistance. Financial support from Princeton University's Center for Economic Policy Studies is gratefully acknowledged. Expressed views and any errors are the author's own responsibility.

\footnotetext{
${ }^{11}$ A more detailed analysis of the optimal way to escape from a liquidity trap and the Foolproof Way, including any international repercussions, is undertaken in Svensson (2003).
} 


\section{References}

Ahearne, Alan, Joseph Gagnon, Jane Haltmaier, Steve Kamin, Christopher Erceg, Jon Faust, Luca Guerrieri, Carter Hemphill, Linda Kole, Jennifer Roush, John Rogers, Nathan Sheets and Jonathan Wright (2002), "Preventing Deflation: Lessons from Japan's Experience in the 1990s," International Finance Discussion Paper No. 729, Federal Reserve Board.

Auerbach, Alan J., and Maurice Obstfeld (2003), "The Case for Open-Market Purchases in a Liquidity Trap," NBER Working Paper No. 9814.

Bank of Japan (2001), TheRole of Monetary Policy under Low Inflation: Deflationary Shocks and Policy Responses, Monetary and Economic Studies 19(S-1), Bank of Japan.

Bank of Japan (2003), Long-Term Time-Series Data, File ecdab015.txt, www.boj.or.jp.

Batini, Nicoletta, and Anthony Yates (2003), "Hybrid Inflation and Price-Level Targeting," Journal of Money, Credit, and Banking 35, 283-300.

Benhabib, Jess, Stephanie Schmitt-Grohé and Martín Uribe (2002), "Avoiding Liquidity Traps," Journal of Political Economy 110, 535-563.

Benigno, Gianluca, and Pierpaolo Benigno (2002), "Implementing Monetary Cooperation through Inflation Targeting," CEPR Discussion Paper No. 3226.

Berg, Claes, and Lars Jonung (1999), "Pioneering Price Level Targeting: The Swedish Experience 1931-1937," Journal of Monetary Economics 43, 525-551.

Bernanke, Ben S. (2000), “Japanese Monetary Policy: A Case of Self-Induced Paralysis?” in Adam Posen and Ryoichi Mikitani, eds., Japan's Financial Crisis and Its Parallels to US Experience, Special Report 13, Institute for International Economics, Washington, DC, 149-166.

Bernanke, Ben S. (2002), "Deflation: Making Sure 'It' Doesn't Happen Here," speech on November 21, 2003, Federal Reserve Board.

Bernanke, Ben S. (2003), "Some Thoughts on Monetary Policy in Japan," speech on May 31, 2003, Federal Reserve Board.

Buiter, Willem H., and Nikolas Panigirtzoglou (1999), "Liquidity Traps: How to Avoid Them and How to Escape Them," working paper.

Cecchetti, Stephen G., and Junhan Kim (2003), "Inflation Targeting, Price Level Targeting, and Output Variability," in Bernanke, Ben S., and Michael Woodford, eds., Inflation Targeting, University of Chicago Press, Chicago, forthcoming. 
Clouse, James, Dale Henderson, Athanasios Orphanides, David Small and Peter Tinsley (2003), "Monetary Policy When the Nominal Short-Term Interest Rate is Zero," Topics in Macroeconomics, www.bepress.com.

Coenen, Günter, and Volker Wieland (2003), "The Zero-Interest-Rate Bound and the Role of the Exchange Rate for Monetary Policy in Japan,” Journal of Monetary Economics, forthcoming.

Corsetti, Giancarlo, and Paolo Pesenti (2003), "International Dimensions of Optimal Monetary Policy," working paper.

The Economist (2002a), “On the Slide,” The Economist, January 5, 2002.

The Economist (2002b), “The Unfinished Recession,” The Economist, September 26, 2002.

Eggertsson, Gauti, and Michael Woodford (2003), "The Zero Bound on Interest Rates and Optimal Monetary Policy," working paper.

European Central Bank (2003), "Key Characteristics of the Euro Area, the United States and Japan; Based on Data for 2001," www.ecb.int.

Feldstein, Martin (2002), "Comment on 'Is There a Role for Fiscal Policy?'," in Rethinking Stabilization Policy, A Symposium Sponsored by the Federal Reserve Bank of Kansas City, Federal Reserve Bank of Kansas City, Kansas City, 151-162.

Fischer, Stanley (2001), "Comments and Discussion," Brookings Papers on Economic Activity 2001:2, 161-166.

Financial Times (2002), "Japan Plays Its Final Card in Battle to Revive Growth," FT.com, January 8, 2002.

Fuhrer, Jeffrey C., and Mark S. Sniderman, eds., (2002), Monetary Policy in a Low-Inflation Environment, Journal of Money, Credit, and Banking 32, 845-1109.

Goodfriend, Marvin (2000), "Overcoming the Zero Bound on Interest Rate Policy," Journal of Money, Credit, and Banking 32, 1007-1035.

International Monetary Fund (2002), "Japan: 2002 Article IV Consultation - Staff Report; Staff Statement; and Public Information Notice on the Executive Board Discussion," IMF Country Report No. 02/175.

International Monetary Fund (2003a), "Deflation: Determinants, Risk, and Policy Options Findings of an Interdepartmental Task Force," International Monetary Fund.

International Monetary Fund (2003b), "World Economic Outlook: A Survey by the Staff of the International Monetary Fund - April 2003," International Monetary Fund. 
Issing, Otmar (2002), “The Euro after Four Years: Is There a Risk of Deflation?" speech on December 2, 2003, European Central Bank.

Jung, Taehun, Yuki Teranishi and Tsutomu Watanabe (2001), "Zero Bound on Nominal Interest Rates and Optimal Monetary Policy," working paper, Hitotsubashi University.

Kashyap, Anil K. (2002), “Sorting Out Japan's Financial Crisis,” Federal Reserve Bank of Chicago Economic Perspectives, 4th Quarter 2002, 42-55.

Krugman, Paul (1998), "It's Baaack! Japan's Slump and the Return of the Liquidity Trap," Brookings Papers on Economic Activity 1998:2, 137-187.

Lebow, David E. (1993), "Monetary Policy at Near Zero Interest Rates," Working Paper No. 136, Division of Research and Statistics, Federal Reserve Board.

McCallum, Bennett T. (2000), "Theoretical Analysis Regarding a Zero Lower Bound on Nominal Interest Rates," Journal of Money, Credit, and Banking 32, 870-904.

McCallum, Bennett T. (2002), "Inflation Targeting and the Liquidity Trap," in N. Loayza and R. Soto, eds., Inflation Targeting: Design, Performance, Challenges, Central Bank of Chile.

McCallum, Bennett T. (2003), "Japanese Monetary Policy 1991-2001," Federal Reserve Bank of Richmond Economic Quarterly 89, forthcoming.

McKinnon, Ronald I. (1999), "Wading in the Yen Trap," The Economist, July 24, 77-79.

Meltzer, Allan H. (2001), "Monetary Transmission at Low Inflation: Some Clues from Japan" Monetary and Economic Studies 19(S-1), Bank of Japan, 13-34.

Meltzer, Allan H. (2003), A History of the Federal Reserve: Volume I, University of Chicago Press, Chicago.

Obstfeld, Maurice, and Kenneth Rogoff (2002), "Global Implications of Self-Oriented National Monetary Rules," Quarterly Journal of Economics 117, 503-36.

Orphanides, Athanasios, and Volker Wieland (2000), "Efficient Monetary Policy Design near Price Stability," Journal of the Japanese and International Economies 14, 327-365.

Posen, Adam S. (1998), Restoring Japan's Economic Growth, Institute for International Economics, Washington, DC.

Sarno, Lucio, and Mark P. Taylor (2001), "Official Intervention in the Foreign Exchange Market: Is It Effective and, If So, How Does It Work?” Journal of Economic Literature 39, 839-868.

Saxonhouse, Gary (1999), “Japan’s Growth Conundrum,” Financial Times, June 14, 1999. 
Sumner, Scott (2002), "Some Observations on the Return of the Liquidity Trap," Cato Journal 21, 481-490.

Svensson, Lars E.O. (1999a), "How Should Monetary Policy Be Conducted in an Era of Price Stability?" in New Challenges for Monetary Policy, A Symposium Sponsored by the Federal Reserve Bank of Kansas City, Federal Reserve Bank of Kansas City, Kansas City, 195-259.

Svensson, Lars E.O. (1999b), "Price Level Targeting vs. Inflation Targeting," Journal of Money, Credit, and Banking 31, 277-295.

Svensson, Lars E.O. (2001), "The Zero Bound in an Open-Economy: A Foolproof Way of Escaping from a Liquidity Trap," Monetary and Economic Studies 19(S-1), Bank of Japan, 277312.

Svensson, Lars E.O. (2002), "Monetary Policy and Real Stabilization," in Rethinking Stabilization Policy, A Symposium Sponsored by the Federal Reserve Bank of Kansas City, Federal Reserve Bank of Kansas City, Kansas City, 261-312.

Svensson, Lars E.O. (2003), "The Magic of the Exchange Rate: Optimal Escape from a Liquidity Trap in Small and Large Open Economies," working paper, www.princeton.edu/ svensson.

Vestin, David (2003), "Price-Level Targeting versus Inflation Targeting in a Forward-Looking Model," working paper. 